African Crop Science Journal by African Crop Science Society is licensed under a Creative Commons Attribution 3.0 Uganda License. Based on a work at www.ajol.info/ and www.bioline.org.br/cs DOI: https://dx.doi.org/10.4314/acsj.v29i1.1

\title{
OLFACTORY RESPONSES OF Sitophilus zeamais L. TO BUSHMINT LEAF POWDER AND METHANOL EXTRACT ON STORED MAIZE
}

\author{
A.M. NOUDEGBESSI, O.Y. ALABI and R. SIKIROU ${ }^{1}$ \\ Department of Crop Protection and Environmental Biology, University of Ibadan, Nigeria \\ ${ }^{1}$ Laboratory of Crop Protection (LDC), National Institute of Agricultural Research of Benin \\ (INRAB), Benin Republic \\ Corresponding author: alabi.jummy@gmail.com
}

(Received 21 April 2020; accepted 20 January 2021)

\begin{abstract}
Bushmint (Hyptis suaveolens Poit) is a weed with pesticidal properties that have been explored in managing pests of agricultural and medicinal importance. The objective of this study was to evaluate the repellence ability of Hyptis suaveolens to prevent infestation of stored maize grain seed. The study involved evaluation of the olfactory responses of adult weevil to maize (Zea mays L.) grains treated with 5, 10, 15 and 20\% concentrations of leaf powder (LP) and methanol extract (ME) of Hyptis suaveolens in the laboratory, with a static air four-chamber olfactometer. Also, the insecticidal effects of the substances on adult mortality and oviposition on maize grains treated with LP and ME were determined in a completely randomised design, with four replicates. The number of weevils in ME chambers decreased with increase in concentration of extracts; while the LP chambers had consistently fewer weevils with numbers, ranging from 2.5 to 3.75. Adult mortality in maize treated with LP was the least and varied between 0.00 (15\% concentration) and $2.54 \%$ ( $20 \%$ concentration). Maize grains with ME caused significant mortalities that ranged from $65.50 \%$ at $15 \%$ concentration to $94.92 \%$ at $10 \%$ concentration. More eggs (3.5 to 5.75) were laid on maize with LP compared with ME treated maize. Generally, ME was richer in phytochemicals than LP. Hyptis suaveolens repellence manifested more in the form of LP than as ME; though ME caused more adult mortality and reduced oviposition than LP.
\end{abstract}

Key Words: Adult mortality, Hyptis suaveolens, Zea mays

\section{RESUME}

La menthe de brousse (Hyptis suaveolens Poit) est une adventice aux propriétés pesticides explorées dans la gestion des ravageurs en agriculture et en médicine. Bien que des données sur son efficacité contre les ravageurs de stocks soient disponibles, sa capacité répulsive contre les insectes de stocks n'a pas été suffisamment documentée. Par conséquent, les réponses olfactives du charançon du maïs en stock traité avec des concentrations de 5, 10, 15 et $20 \%$ de poudre de feuilles d' $H$. suaveolens (LP) et de son extrait méthanolique (ME) ont été étudiées au laboratoire à l'aide d'olfactomètre à quatre compartiments à air statique. De même, les effets insecticides des substances sur la mortalité des 
adultes et la ponte sur les grains de maïs traités avec LP et ME ont été déterminés suivant un dispositif complètement aléatoire à quatre répétitions. Le LP et le ME ont été analysés pour leurs composés phytochimiques. Le nombre de charançons dans les compartiments ME diminuait avec l'augmentation de la concentration d'extrait, tandis que les compartiments LP avaient constamment moins de charançons avec des nombres variant entre 2,5 à 3,75. Le pourcentage de mortalité d'adultes dans le maïs traité avec LP était le plus faible et variait entre 0,00 (concentration 15\%) et 2,54\% (concentration 20\%). Le maïs traité avec ME causait des mortalités significatives allant de $65,50 \%$ pour une concentration de $15 \%$ à $94,92 \%$ pour $10 \%$ de concentration. Le nombre le plus élevé d'œufs $(3,5$ à 5,75$)$ a été pondu sur du maïs traité avec LP, tandis que le nombre le plus faible $(1,0)$ a été enregistré sur celui traité au ME. Des concentrations significativement élevées de composés phytochimiques étaient obtenues dans ME comparativement à LP. Le maïs traité avec LP était hautement répulsif pour Sitophilus zeamais, tandis que celui traité avec ME causait la mortalité des adultes et réduisait la ponte.

Mots Clés : Mortalité d'Adulte, Hyptis suaveolens, Zea mays

\section{INTRODUCTION}

Insect pests threaten food security in west Africa, accounting for 30-40\% of yield losses annually in maize (Zea mays, L.) (Boxall, 2002; Ojo and Omoloye, 2012; Abraha et al., 2018). Among the insect pests of maize, Sitophilus zeamais Motschulsky (maize weevil), is considered as a major pest in storage world over. Infestations by the pest not only cause significant economic losses, but also result in elevated temperatures and moisture conditions that lead to an accelerated growth of moulds, including toxigenic fungal species (Megan et al., 2003). The weevil feeds on the germ of maize grains, thereby reducing the protein content of the grains (Effiong and Sanni, 2009). Adult weevils and larvae feed on maize grains and reduce them to powdery form (Longe, 2016).

To overcome the insect pest problem and to extend the maize storage shelf life, several chemical insecticides have been developed and used (Sikirou et al., 2015). Unfortunately, unregulated use of chemical insecticides engenders many problems, including environmental pollution, residual toxicity, death of non-target organisms, risk of user's contamination and promotes pest resistance (Ouko et al., 2017). This led researchers to think of a better alternative, such as biopesticides (Conti et al., 2011, Kumar, 2015;
Kamrul et al., 2018). Biopesticides are substances derived from materials such as animals, plants, bacteria and minerals (Kumar, 2015). Farmers reportedly use natural products such as neem leaves, bitter leaves, pepper, ashes, to preserve stored grains (Schneider, 2015). Insecticidal activities of leaf, stem, bark and root from different plants (Eucalyptus globulus Labill, Jacaranda mimisifolia D. Don, Matricaria chamomilla L., Tagetes minuta L., Ocimum tenuiflorum L., Moringa oleifera, Hyptis spicigera Lamarck and Hyptis suaveolens (L.) Poit (Barbara et al., 2010; Alabi and Adewole, 2017; Sekyere et al., 2018) have been explored for the management of stored products, with mostly promising results.

Originally native to tropical America, Bushmint (Hyptis suaveolens Poit) is considered as a weed (Ngozi et al., 2014) with pesticidal properties that have proven effective in managing pests of agricultural importance and for medicine (Conti et al., 2011; Olotuah, 2013). The larvicidal and repellent activity of $H$. suaveolens essential oil against the mosquito Aedes albopictus Skuse (Diptera: Culicidae) was investigated by Conti et al. (2011). They found that at the highest dosages of 450 and 400 ppm, there were no significant differences on larval mortality between Hyptis suaveolens and synthetic insecticide. Olotuah (2013) reported that essential oils from Hyptis 
suaveolens using $\mathrm{n}$-hexane, diethyl ether and methanol as solvents repelled Sitophilus oryzae, S. zeamais and Callosobruchus maculatus. In particular, the methanolic extract at $100 \%$ concentrations against Sitophilus zeamais through contact treatment caused $100 \%$ mortality of the insects.

Previous studies have established the insecticidal potency of methanol extract from Hyptis suaveolens leaves against stored product and field pests, this suggests that the leaf of $H$. suaveolens has potent insecticidal properties. However, there is dearth of information on the biological activity of the leaf powder, and not extracts, since resource poor farmers in Africa can easily prepare the powder than compounding any extract; this would be a beneficial study to investigate. Therefore, the objective of this study was to evaluate the olfactory responses of $S$. zeamais to $H$. suaveolens leaf powder and methanol extract and their effects against survival of adult weevils.

\section{MATERIALS AND METHODS}

Fresh leaves of $H$. suaveolens were collected from the roadside of Abomey-Calavi south of Benin. The leaves were washed with distilled water, chopped into small pieces, and shadedried at room temperature $\left(26 \pm 1^{\circ} \mathrm{C}\right)$ for 21 days. Then, the dried leaves were ground into powder using a laboratory grinder (Bender and Hobein 8042 Zurich) and kept at room temperature of $25-27{ }^{\circ} \mathrm{C}$ until use. The ground powder was used as the leaf powder in all experiments.

To prepare the methanol extract from leaves, leaf powder $(50 \mathrm{~g})$ prepared above was mixed with $500 \mathrm{ml}$ of methanol for 2 hours, at $40{ }^{\circ} \mathrm{C}$ with a magnetic stirrer (IKA C-MAG HS7). The solution was subsequently filtered through Whatmann filter paper, and the resulting filtrate was evaporated off using a Rotavapor (BUCHI RII), at $47{ }^{\circ} \mathrm{C}$ to remove the solvents completely. The methanol extracts were stored in falcon tubes at $4{ }^{\circ} \mathrm{C}$.
Insect rearing. Adults of $S$. zeamais were collected from maize stores in Dantokpa market in the Republic of Benin. Five kilner jars, each of $1 \mathrm{~kg}$ capacity, were used for insect production. Each kilner jar contained $500 \mathrm{~g}$ of local variety "Gbadé wéwé" of maize grains (white maize), purchased from Comè market, Republic of Benin. The $500 \mathrm{~g}$ of maize in each jar, were infested with 50 pairs of newly emerged adults of $S$. zeamais, and allowed to lay eggs for one week. The first generation of emergent adults was used for all experiments.

Olfactometer experiments. The responses of adult maize weevils to odours from powder and methanol extract of different concentrations $(5,10,15$ and $20 \%)$ were examined using a Static Air Four-Chamber Olfactometer in the laboratory. The Olfactometer was a cylindrical acrylic glass (4 $\mathrm{cm}$ high, $19 \mathrm{~cm}$ diameter), divided with vertical plates into four chambers. On the top of the cylinder, a walking arena $(1 \mathrm{~cm}$ high, $19 \mathrm{~cm}$ diameter) was placed consisting of plastic gauze (mesh $0.5 \mathrm{~mm}$ ) with a rim of plastic $(0.9 \mathrm{~cm}$ high $)$, and covered with a glass plate according to Gross and Mekonen, (2005). No air flow was generated; this was to simulate a storage system scenario.

Odours emanating from the treated and untreated grains were allowed to diffuse through the gauze, resulting in an odour field in the walking arena above. Both powder and methanol extract from Hyptis suaveolens leaf were individually incorporated into $200 \mathrm{~g}$ maize grains at $0 \%$ (control, untreated) 5, 10, 15 and $20 \%(\mathrm{w} / \mathrm{w})$. A sample $(20 \mathrm{~g})$ of treated maize with either extract or powder at given concentrations, was placed in two opposite chambers.

Two chambers containing untreated maize grains acted as controls. Ten insects were released individually in the centre of the walking arena; and their arrestment times in the four sectors above the arena was recorded every 1 hour, for 4 hours. To avoid bias due to possible orientation preferences of the insects, the 
position of the Olfactometer was rotated clockwise by $90^{\circ}$ at each 1 hour. Each experiment was repeated four times. Protect DP (Pirimiphos-methyl 1.5\% + Deltamethrine $0.1 \%$ ) was included as a control. It was used

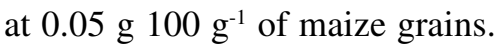

The insecticidal effects of $H$. suaveolens test materials on adult weevil mortality and oviposition were determined in the laboratory using the following procedures.

Leaf powder (LP). Maize grains variety, "Gbadé wéwé", were kept in a deep freezer, at $-20{ }^{\circ} \mathrm{C}$ for 1 week (Danho et al., 2015) to ensure that any existing insect eggs and larvae were killed before starting the experiment. Ten, 20,30 and $40 \mathrm{~g}$ of leaf powder, corresponding to 5,1015 and $20 \% \mathrm{w} / \mathrm{w}$ concentrations, respectively, were added to approximately 200 $\mathrm{g}$ of clean undamaged maize (Gbadé wéwé) grains in plastic containers; (each of $300 \mathrm{~g}$ capacity) covered with muslin cloth. The grains were mixed with the powder thoroughly for approximately 30 seconds before transferring the treated grains into bioassay containers, according to Ajani (2018). The binary insecticide (Pirimiphos-methyl 1.5\% + Deltamethrine $0.1 \%$ ), with the trade name 'PROTECT'DP, was used as positive control; while the negative control was untreated grains. The effect of methanol on the weevil was also verified. Fifty pairs (25 males: 25 females) from the first generation F1 were introduced in each plastic container containing grains treated with leaf powder and the two controls.

Methanol Extract (ME). The insecticidal activity of $H$. suaveolens was assessed by dissolving 1, 2, 3 and $4 \mathrm{~g}$ of methanol leaf extracts, each in $20 \mathrm{ml}$ of methanol; corresponding to $5,10,15$ and $20 \% \mathrm{w} / \mathrm{v}$, respectively. Clean undamaged maize grains $(200 \mathrm{~g})$ were dipped in $7 \mathrm{ml}$ of each of the different concentrations of leaf extracts; and manually thoroughly mixed for approximately 30 seconds. The mixtures were left for 1 hour to allow methanol to evaporate before infestation; each set up was covered with muslin cloth. Protect DP was used as the positive control, and untreated grains as the negative control.

Fifty pairs (25 males: 25 females) of Sitophilus zeamais from the first generation F1 were introduced into each of the plastic cages containing grains treated with the methanol extract, and into the two controls. The experimental variants (LP and ME) were replicated four times in a completely randomised design. Adult mortality was recorded at 2, 4, 7 and 14 days after treatment. The percentage mortality was determined as follow:

Percentage morality $=$

Number of dead insects

$\longrightarrow$ x 100

Total number of insects

Data on percentage mortality were corrected using Abbott's formula (Abbott, 1925)

$$
\mathrm{P} t=\frac{\mathrm{P} o-\mathrm{P} c}{100-\mathrm{P} c} \times 100
$$

Where:

$\mathrm{P} t=$ Corrected mortality $\mathrm{P} o=$ Treated variants mortality; and $\mathrm{P} c=$ Control mortality.

Oviposition was assessed seven days after infestation, by counting the number of eggs laid on a sample of 100 grains taken from each variant plastic container. Sitophilus zeamais females deposited single eggs in holes bored into the grain, and sealed with a gelatinous egg plug which stained cherry red with acid fuchsin (Danho et al., 2015).

The method used to stain the egg plugs was adapted from that of Holloway (1985). It involved soaking grains for 1 to 2 minutes in warm water $\left(25-30{ }^{\circ} \mathrm{C}\right)$; followed by immersion for 1 to 2 minutes in an acid fuchsin solution ( $0.5 \mathrm{~g} \mathrm{~L}^{-1}$ of water). The maize grains were finally rinsed with distilled water to eliminate excess staining solution, and then 
dried on filter paper for 60 minutes at room temperature. The egg plugs appeared cherry red in colour, when observed under a stereomicroscope.

Phytochemical analysis of test materials. The quantity of saponins was determined using Obadoni and Ochuko (2001) method. Tannin content was determined by Folin - Ciocalteu method. Total flavonoid content was measured by the aluminium chloride colorimetric assay (Obadoni and Ochuko, 2001). Hager's test was conducted to determine the alkaloids in H. suaveolens (Harborne, 1973). The presence of phenols was determined by Ferric Chloride's test; density was measured at 760 $\mathrm{nm}$ against a blank. The total phenolic contents were calculated on the basis of the calibration curve of Gallic acid and expressed as Gallic Acid equivalents (GAE), in milligrammes per gramme of the sample (Singleton et al., 1999).

Statistical analysis. Statistical analysis was carried out using $R$ version 3.5.0 software ( $R$ core Team, 2019). Responses of $S$. zeamais in the static air four-chamber olfactometer to LP and ME odours were analysed using Student's t-test at 0.05 level of significance. Data on adult mortality and number of $S$. zeamais eggs were analysed using Analysis of variance (ANOVA) and means were separated using Student Newman Keuls (SNK) test at 0.05 level of significance.

\section{RESULTS}

Responses of maize adult weevils to treatments. The number of adult weevils in the untreated compartments of the olfactometer was significantly higher $(\mathrm{P}<0.05)$ than that in treated compartments with Protect DP and LP (Table 1). However, in the ME set up, the number of $S$. zeamais in treated compartment decreased with the increasing bio-extract concentrations; from 6.5 (5\% ME) to 2.5 (20\% $\mathrm{ME})$, and increased in untreated compartment from 3.5 (5 ME) to 7.5 (20 ME) (Table 1).

Adult weevil mortality. There was no significant $(\mathrm{P}>0.05)$ effect of concentration of leaf powder on mortality of $S$. zeamais. Adult mortality was very low on grains treated with the different concentrations of leaf powder (Fig. 1). Mortalities recorded on maize treated with methanol extracts were remarkably high $(\mathrm{P}<0.05)$ for all concentrations; and varied between 60.50 and $100 \%$, especially at 7 days after treatment for 5 to $15 \%$ concentrations and reached 98.50 at $20 \%$ concentrations, 2 days after exposure (Fig. 1). Grains treated with Protect DP resulted in high mortality of S. zeamais, ranging from $98.50 \%$ (2 days after

TABLE 1. Number of Sitophilus zeamais in chambers with odours of Hyptis suaveolens leaf powder, methanol extract, Protect and untreated chambers

\begin{tabular}{lccc}
\hline Variant & Treated chamber & Untreated chamber & P values \\
\hline Protect DP & $3.25 \pm 1.89$ & $6.75 \pm 1.89$ & $0.040^{*}$ \\
5LP & $2.5 \pm 1.29$ & $7.5 \pm 1.29$ & $0.000^{*}$ \\
10LP & $2.75 \pm 0.96$ & $7.25 \pm 0.96$ & $0.000^{*}$ \\
$15 \mathrm{LP}$ & $2.5 \pm 0.58$ & $7.5 \pm 0.58$ & $0.000^{*}$ \\
20LP & $3.75 \pm 1.26$ & $6.25 \pm 1.26$ & $0.030^{*}$ \\
$5 \mathrm{ME}$ & $6.5 \pm 1.29$ & $3.5 \pm 1.29$ & $0.020^{*}$ \\
$10 \mathrm{ME}$ & $4.25 \pm 0.50$ & $5.75 \pm 0.50$ & $0.010^{*}$ \\
$15 \mathrm{ME}$ & $3.75 \pm 0.96$ & $6.25 \pm 0.96$ & $0.010^{*}$ \\
$20 \mathrm{ME}$ & $2.5 \pm 1.29$ & $7.5 \pm 1.29$ & $0.000^{*}$ \\
\hline
\end{tabular}

$\mathrm{LP}=$ leaf powder; $\mathrm{ME}=$ methanol extract, $*=$ significant at $\mathrm{P}<0.05$ 


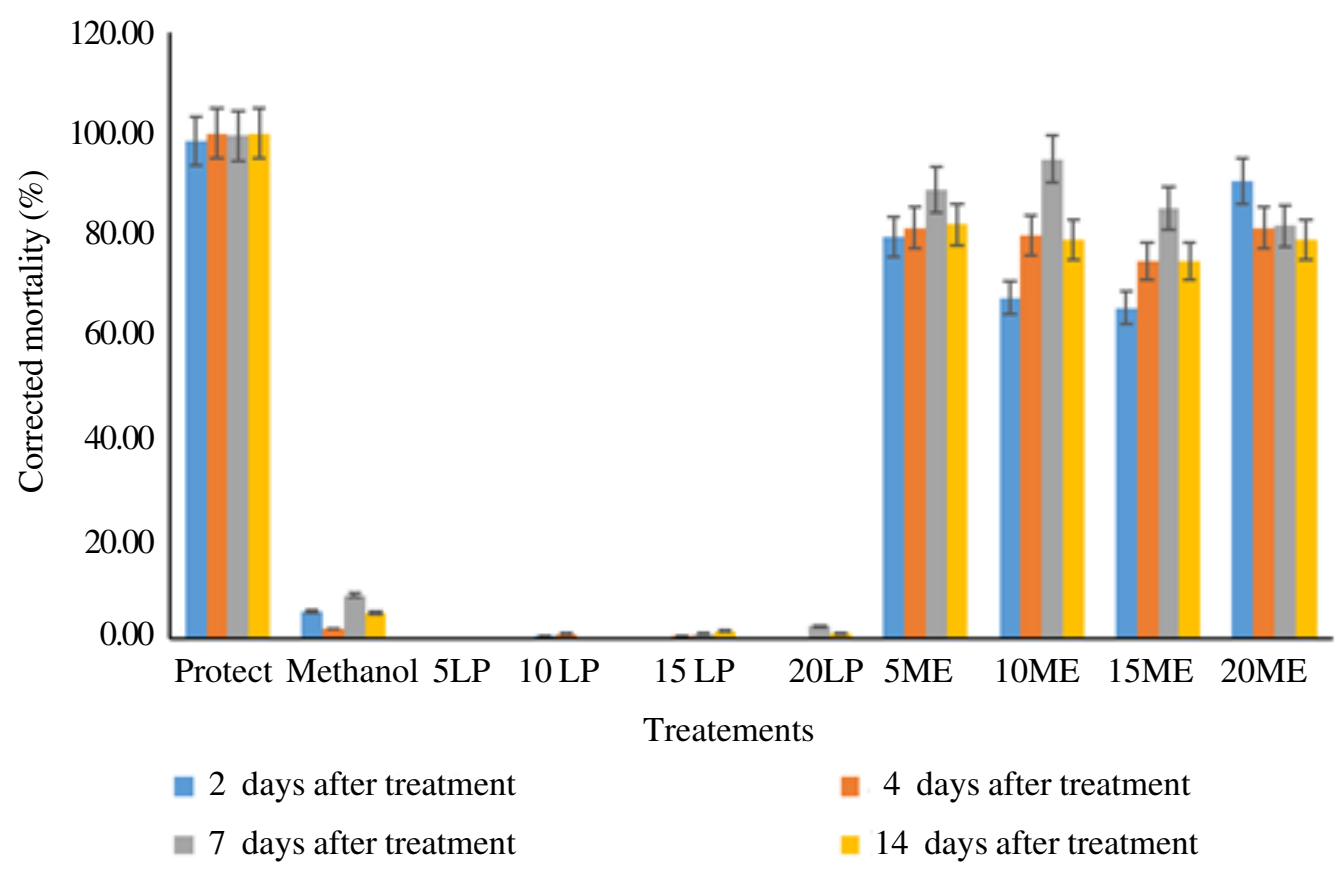

Figure 1. Adult mortality (\%) on maize treated with leaf powder, methanolic extract of Hyptis suaveolens and Protect DP.

treatment) to $100 \%$ (14 days after treatment) (Fig. 1).

Oviposition of adult weevils. The number of $S$. zeamais eggs laid on maize treated with H. suaveolens leaf powder, methanol extract and Protect DP are presented in Figure 2. The number of eggs laid on maize grains treated with different concentrations of leaf powder were significantly higher than that laid on maize coated with different concentrations of methanol extract $(\mathrm{P}<0.05)$. No eggs were laid on maize grains coated with 10 and $20 \%$ methanol extracts and the effect was not significantly different from $5 \%$ methanol extract (1.00). Few eggs (0.75) were laid on grains treated with Protect DP. There was no significant difference $(\mathrm{P}>0.05)$ between the number of eggs laid on untreated grains (3.5) and treated grains with $H$. suaveolens leaf powder (Fig. 2).

Phytochemical constituents of the extracts. Hyptis suaveolens leaf contained saponins, tannins, alkaloids, flavonoids and total phenols as phytochemicals (Table 2). Phytochemicals were very high when extracted with methanol but very low in leaf powder with highest concentration of saponins in leaf powder and methanol extract and lowest concentration of Tannins.

\section{DISCUSSION}

From our result, it was found out that the number of eggs laid on maize grains treated with different concentrations of leaf powder were higher than that laid on maize coated with different concentrations of methanol extract. This can be explained by the fact that Hyptis methanol extract adhered more to the grains than Hyptis powder, which easily rubs off the grain and then facilitate the oviposition of maize weevils.

The number of weevils in leaf powder compartments were consistently lower across all the concentrations compared with the untreated (control) compartments. This means that the weevils preferred the untreated compartments containing clean grains, to 


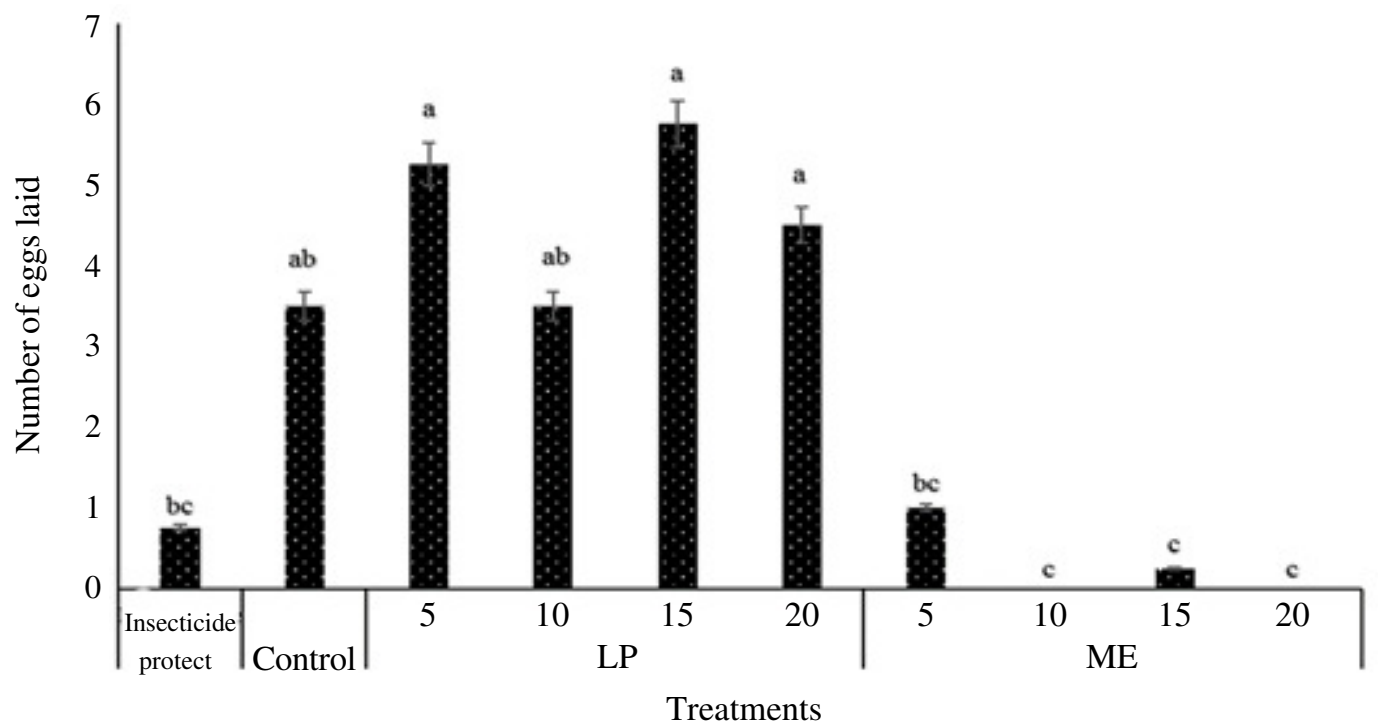

Figure 2. Number of eggs laid by Sitophilus zeamais on maize grains treated with Hyptis suaveolens leaf powder, methanolic extract and Protect DP.

TABLE 2. Quantitative phytochemical screening of Hyptis suaveolens leaf powder and methanol extract

\begin{tabular}{lcc}
\hline Phytochemical & Hyptis suaveolens leaf powder & Hyptis suaveolens methanol extract \\
\hline Saponin $(\%)$ & $8.09 \pm 0.00$ & $14.38 \pm 0.00$ \\
Tannin $\left(\mathrm{mg} \mathrm{g}^{-1}\right)$ & $0.35 \pm 0.001$ & $1.63 \pm 0.005$ \\
Alkaloid $(\%)$ & $2.56 \pm 0.00$ & $10.35 \pm 0.02$ \\
Flavonoid $\left(\mathrm{mg} \mathrm{g}^{-1}\right)$ & $0.59 \pm 0.003$ & $4.75 \pm 0.012$ \\
Total phenol $\left(\mathrm{mg} \mathrm{g}^{-1}\right)$ & $1.14 \pm 0.004$ & $5.53 \pm 0.005$ \\
\hline
\end{tabular}

compartments exuding leaf powder odours. This suggests that the leaf powder contain bioactive compounds as was reported by Noudogbessi et al (2013) and Adou et al. (2019) who stated that several volatile organic compounds (Sabinene (7.3-31.3\%), eucalyptol (14.0-24.6\%), $\beta$-caryophyllene (6.9-12.7\%), 1,8 -cineole $(11.5 \%), \beta$-phellandrene $(10.2 \%)$, terpinolene (8.7-9.6\%), fenchone (4.1-8.1\%), p-mentha-2 (7), 8-diene $\quad(7.9 \%)$, bicyclogermacrène (4.7-7.5\%), $\beta$-pinene (4.9$7.4 \%),(\mathrm{Z})$ - $\beta$-ocimene $(6.9 \%)$ and terpinen4-ol (5.4-5.9\%) were found in essential oil extracted from $H$. suaveolens leaves. These compounds in $H$. suaveolens leaf according to Noudogbessi et al. (2013) and Adjou et al. (2019) have pesticidal properties.

Our result show that the number of adult weevils reduced as the concentration of leaf powder increased. The explanation of this result is that the leaf powder exude volatile compounds that repelled the weevils from the treated compartments. This is a first report that demonstrates that volatile compounds emanating from the leaf powder of Hyptis suaveolens repelled Sitophilus zeamais. Hence, small holder farmers could easily apply the plant powder on stored maize grain to forestall weevil infestation. 
Also from our study, the number of weevils decreased with increase in concentrations of methanol extract but not as obvious as in the leaf powder. Hence, the methanol extract exuded low concentrations of odours that was lower compared with the leaf powder. The interesting aspect of these results is the low quantities of leaf powder needed to repel the weevil, hence a smallholder farmer would need a small quantities of leaf powder to protect maize grains against weevil infestation.

The leaf powder of $H$. suaveolens did not result in mortality of adult maize weevil. Although the powder repelled the weevils in the olfactory experiment, it did not possess the ability to cause death of the insects. The maize grains had smooth surfaces that did not permit the powder of Hyptis suaveolens to stick to them. Therefore, the adults could lay eggs, hence the higher number of eggs recorded on grains treated with the leaf powder.

In the case of the methanol extract, the high adult mortality on treated maize grains right from the second day of treatment application, also suggests that the methanol extract contained lethal compounds that killed the insects possibly through contact and feeding. The marked death of adult weevils from the second day after treatment, implies that the number of eggs laid at 7 days after treatment will be considerably reduced. Many of the adults that should lay eggs by one week after treatment had died earlier. Indeed, there were no eggs laid on maize grains treated with 10 and $20 \%$ methanol extract.

Similar results were reported by several researchers who noted that repellent and toxicity of extracts from leaf and seed of $H$. suaveolens (Musa et al., 2009; Pavunraj et al, 2014). Methanol extract from seed and leaf of $H$. suaveolens enhanced khapra beetle (Trogoderma granarium Everts) adult mortality, reduced its oviposition and suppressed larval and adult emergence from stored groundnuts (Musa et al., 2009). Pavunraj et al (2014) reported antifeedant and insecticidal activity of ethyl acetate leaf extract of $H$. suaveolens against some lepidopteran pests.
Both the leaf powder and methanol extract contained saponin, tannin, alkaloid, flavonoid and total phenol. However, leaf powder was poorer in these substances that its methanol extract counterpart. Thus, the high concentrations of the phytochemicals in methanol extract were responsible for the adult mortality.

From previous reports, there are variations in the phytochemicals obtainable from Hyptis suaveolens; although this is not peculiar to Bushmint, but to all plants generally (Akob and Ewete, 2007; Ukeh et al., 2009; Noudogbessi et al., 2013). Endogenous (genetic, development, etc.), botanical source, edaphic and climatic factors could alter the chemical composition of plants (Akob and Ewete, 2007; Ukeh et al., 2009; Noudogbessi et al., 2013). Hence there is the need to always conduct phytochemical screening of plant materials when they are explored for insecticidal properties.

It is clearly evident from the laboratory experiments in this study that the modes of action of the leaf powder is repellence against weevils and that of methanol extract was contact toxicity and antifeedant against the weevils. Hyptis suaveolens leaf powder and methanol extract could be put into multiple uses based on the intent of the user or applicator. Leaf powder of $H$. suaveolens when applied to newly stored maize grains will reduce rapid colonisation of grains by the weevils. On the other hand, if the produce had been infested with weevils, application of methanol extract will rapidly decimate pest population on the stored grains as quickly as a synthetic insecticide would also act. Consequently, there will be reduction in number of eggs laid by surviving weevils and subsequent F1 generation. This is a novel approach in the protection of stored maize from weevil attack and damage.

Further studies should be carried out to determine the volatile organic compounds (odours) in the leaf powder and the most potent compounds could be synthesized and formulated into dusts that farmers and house 
wives can easily apply to stored grains to ward off weevils infestation.

\section{CONCLUSION}

Hyptis suaveolens is a potential biopesticide which could be used as preventive and curative substance against Sitophilus zeamais infestation on stored maize as established from the results of this study. $H$. suaveolens methanol extract is also highly effective as an insecticide, while the leaf powder is efficacious as a repellent against $S$. zeamais. Both Leaf Powder and Methanol extracts contain saponin, tannin, alkaloid, flavonoid and phenol as phytochemicals; the former is richer than the latter. However, the specific causes of repellence in Leaf Powder, and phytotoxicity in methanol extract and the bioactive compounds of $H$. suaveolens need further elucidation.

\section{ACKNOWLEDGEMENT}

The authors are grateful to West African Agricultural Productivity Programme (WAAPP-Benin) for financial support of this research work.

\section{REFERENCES}

Abere, T.A., Oguwike, E. and Sumaila, M. 2016. Pharmacognostic standardization and insecticidal activity of the leaves of Hyptis suaveolens (L.) Poit (Lamiaceae). Journal of Pharmacy and Bioresources 13(2):163-170.

Abbott, W.S. 1925. A method of computing the effectiveness of an insecticide. Journal of Economic Entomology 18:265-267.

Abraha, H.R., Abraha, K.Z., Gebreslassie, W.L. and Beyene W. 2018. Assessment of production potential and post-harvest losses of fruits and vegetables in northern region of Ethiopia. Agriculture and Food Security 7(29):1-13.
Adégbola, P.Y., Arouna, A. et Ahoyo, N.R.A. 2011. Acceptabilité des structures améliorées de stockage du maïs au SudBénin. Bulletin de la Recherche Agronomique du Bénin - Numéro spécial 2 : Aspects économiques du stockage et de la conservation du maïs au Sud-Bénin. $12 \mathrm{pp}$.

Adesoji, A.G., Abubakar, I.U and Labe, D.A. 2016. Economic performance of maize under incorporated legumes and nitrogen in Northern Guinea Savanna Zone of Nigeria. Asian Journal of Agricultural Research 10(1):38-46.

Adjou, E.S., Chougourou, D. and Soumanou, M.M. 2019. Insecticidal and repellent effects of essential oils from leaves of Hyptis suaveolens and Ocimum canum against Tenebroides mauritanicus (L.) isolated from peanut in post-harvest. Journal of Consumer Protection and Food Safety 14:25-30. https://doi.org/10.1007/ s00003-018-1195-4

Ajani, A.I. 2018. Bioactivity of powder and methanol extract of Sida acuta Burm F. leaf against Sitophilus zeamais Motschulsky on stored maize. MSc. Project. University of Ibadan, Nigeria. $51 \mathrm{pp}$.

Akob, C.A. and Ewete F.K. 2007. The efficacy of ashes of four locally used plant materials against Sitophilus zeamais (Coleoptera: Curculionidae) in Cameroon. International Journal of Tropical Insect Science 27(1): 21-26. doi: 10.1017/S1742758407699615.

Alabi, O.Y. and Adewole, M.M. 2017. Essential oil extract from Moringa oleifera roots as cowpea seed protectant against cowpea beetle. African Crop Science Journal 25(1): 71-81.

Amegnaglo, C.J. 2018. Determinants of maize farmers' performance in Benin, West Africa, Kasetsart. Journal of Social Sciences 30: 1-7. https://doi.org/10.1016/j.kjss.2018. 02.011 .

Bhusal, K. and Khanal, D. 2019. Role of maize weevil, Sitophilus zeamais Motsch. on 
Spread of Aspergillus section flavi in different Nepalese maize varieties. Hindawi Advances in Agriculture 10:1-5.

Boxall, R. 2002. Damage and loss caused by the larger grain borer Prostephanus truncatus. Integrated Pest Management Review 7:105-121.

Barbara, C., Angelo, C., Pier Luigi, C. and Guido, F. 2010. Repellence of essential oils from tropical and Mediterranean Lamiaceae against Sitophilus zeamais. Bulletin of Insectology 63(2):197-202.

Conti, B., Benelli, G., Flamini, G., Cioni, P. L., Profeti, R., Ceccarini, L. and Macchia, M and Canale, A. 2011. Larvicidal and repellent activity of Hyptis suaveolens (Lamiaceae) essential oil against the mosquito Aedes albopictus Skuse (Diptera: Culicidae). Parasitology Research (2012) 110:2013-2021.

Core Team R. 2013. A language Wed environment for statistical computing: $\mathrm{R}$ Foundation for statistical computing, Vienna, Austria, http:/www.R-project.org/ . Accessed 24 February 2019.

Danho, M., Alabi, T., Haubruge, E. and Francis, F. 2015. Oviposition strategy of Sitophilus zeamais Motsch. (Coleoptera: Curculionidae) in relation to conspecific infestation. African Journal of Agricultural Research 10(4):301-307.

Effiong, B. and Sanni, A. 2009. Effect of Duckweed meal on the rate of moulds infestation in stored pelleted fish feed. Journal of American Science 1(5):29-34.

Ekaette, E., Eno, A., Joseph, E. and Emem, E. 2012. Bio-insecticidal potentials of testa powder of melon, Citrullus vulgaris Schrad for reducing infestation of maize grains by the maize weevil, Sitophilus zeamais Motsch. Journal of Biology, Agriculture and Healthcare 2(8):13-17.

FAO. 2018. FAOSTAT for 2018. Food and Agricultural organization of the United Nations: Rome, Mars 2019, http:// www.fao.org/faostat/en/\#home.
Gross, J. and. Mekonen, N. 2005. Plant odours influence the host finding behaviour of apple psyllids (Cacopsylla picta; $C$. melanoneura). International Organisation for Biological and Integrated Control West Palaearctic Regional Section Bulletin 28: 351-355.

Harborne, J.B. 1973. Phytochemical Methods. Chapman and hall Ltd., London: U.K. pp 49-188.

Holloway, G.J. 1985. The effect of increased grain moisture content on some life history characters of Sitophilus oryzae (L.) after staining egg plugs with acid fuchsin. Journal of Stored Products Research 21: 165-169.

Iloba, B.N. and Ekrakene, T. 2006. Comparative assessment of insecticidal effect of Azadirachta indica, Hyptis suavoelens and Ocimum gratissimum on Sitophilus zeamais and Callosobruchus maculatus. Journal of Biological Sciences 6(3):626-630.

Jeeva, S. and Johnson, M. 2012. Anti-bacterial and phytochemical studies on methanolic extracts of Begonia floccifera Bedd. flower. Asian Pacific Journal of Tropical Biomedicine 2:151-154.

Jose, S.S., Joselin, J., Florence, A.R., Shynin Brintha, T.S. and Jeeva, S. 2014. Phytochemical constituents of the leaf of Plumbago zeylanica L. a common understorey species of homestead agroforests of Kanyakumari District, Tamilnadu. International Journal of Pharmaceutics 4(3):162-165.

Joseph, J. and Jeeva, S. 2016. GC-MS and FT-IR analysis of a coastal medicinal plantHyptis suaveolens (L.) Poit. Journal of Coastal Life Medicine 4(5):380-385.

Kamrul, H., Abdullah, A.N., Shabnam, S., Meherun, N., Meherunnesa, K. and Nurul, I. 2018. Control potentials of Hyptis suaveolens L. (Poit.) extracts against Artemia salina L. Nauplii and Tribolium castaneum (HBST.) adults. Journal of 
Entomology and Zoology Studies 6(1): 785-789.

Kasim, I., Mad Nasir, S., Rusli, Y. and Alias, B. R. 2014. Technical efficiency in maize production and its determinants: A survey of farms agro ecological zones in Northern Nigeria. Trend in Agricultural Economics 7(2):57-68.

Koul, O. 2008. Phytochemicals and insect control: An antifeedant approach. Critical Reviews in Plant Sciences (27):1-24.

Keita, S.M., Vincent, C., Schmit, J., Ramaswamy, S. and Belanger, A. 2000. Effect of various essential oils on Callosobruchus maculatus (F.) (Coleoptera, Bruchidae). Journal of Stored Product Research 36:349-355.

Kumar, S. 2015. Biopesticide: An environment friendly pest management strategy. Journal of Biofertilizers and Biopesticides 6(1):13 .

Longe, O.O. 2016. Ecology, life cycle and ways of subjugating the maize weevil Sitophilus zeamais in Storage. International Journal of Agriculture and Environmental Research 12(2):298-313.

Megan, N., Hope, R., Cairns, V. and Aldred, D. 2003. Postharvest fungal ecology: Impact of fungal growth and myco-toxin accumulation in stored grain. European Journal of Plant Pathology 109:723-730.

Musa, A.K., Dike, K.C. and Onu, I. 2009. Evaluation of nitta (Hyptis suaveolens Poit.) seed and leaf extracts and seed powder for the control of Trogoderma granarium Everts (Coleoptera: Dermestidae) in stored groundnut. American-Eurasian Journal of Agronomy 2(3):176-179.

Ngozi, L.U., Ugochukwu, N., Ifeoma, P.U., Charity, E.A. and Chinyelu, E.I. 2014. The efficacy of Hyptis suaveolens: A review of its nutritional and medicinal applications. European Journal of Medicinal Plants 4(6): 661-674.

Noudogbessi, Jean-Pierre, Agbangnan, P., Yehouenou, B., Adjalian, E., Nonviho, G., Akibou Osseni, M., Wotto, V., Figueredo,
G., Chalchat, Jean-Claude and Sohounhloue, D. 2013. Physicochemical properties of Hyptis suaveolens essential oil. International Journal of Medicinal and Aromatic Plants 3(2):191-199.

Obadoni, B.O and Ochuko, P.O. 2001. Phytochemical studies and comparative efficacy of the crude extracts of some homostatic plants in Edo and Delta States of Nigeria. Global Journal of Pure Applied Sciences 8:203-208.

Offiah, E.O. 2015. Sustainability of maizebased production system in Anambra State Nigeria. MSc. Project. University of Nigeria, Nsukka, Nigeria. 83pp.

Ojo, O.C. and Giwa, H.J. 2017. Antimicrobial potential of extracts of Hyptis suaveolens (L.) Poit. Leaves on some gram positive bacterial isolates. Journal of Advances in Medical and Pharmaceutical Sciences 12(4):1-11.

Ojo, J.A. and Omoloye, A.A. 2012. Rearing the maize weevil, Sitophilus zeamais, on an artificial maize-cassava diet. Journal of Insect Science 12(69):1-9.

Olotuah, O.F. 2013. Laboratory evaluation of pesticidal activities of Hyptis suavoelens in pest management. International Journal of Agricultural Research 8(2):101-106.

Oparaeke, A.M., Dike, M.C. and Onu, L. 2002. Control of Callosobruchus maculatus (F.) on stored cowpea with African curry (Ocimum gratissimum L.) and African bush tea (Hyptis suaveolens Poit.) leaf powders. Nigerian Journal of Entomology (19):99108.

Ouko, R.O., Koech, S.C., Arika, W.M., Njagi, S.M., Oduor, R.O. and Ngugi, M.P. 2017. Bioefficacy of organic extracts of Ocimum basilicum against Sitophilus Zeamais. Entomology, Ornithology and Herpetolog: Current Research 6(1):1-7.

Pavunraj, M,. Baskar, K., Paulraj, M.G., Savarimuthu Ignacimuthu, S. and Janarthanan, S. 2014. Phagodeterrence and insecticidal activity of Hyptis suaveolens (Poit.) against four important lepidopteran 
pests. Archives of Phytopathology and Plant Protection 47(1):113-121. doi: 10.1080/03235408.2013.800694

Prasanna, S.R. and Koppula, S.B. 2012. Antimicrobial and preliminary phytochemical analysis of solvent extracts of Hyptis suaveolens from banks of River Krishna. International Journal of BioPharma Research 1(1):11-15.

Schneider, K. 2015. Gestion post-récolte en Afrique Subsaharienne, stude de faisabilité pour la promotion de technologies postrécolte améliorées dans deux régions du Bénin. Rapport de Mission Kurt Schneider, Consultant Cotonou / Guatemala 30(4):826.

Sekyere, P.A., Mbatchou, V.C., Dickson, A. and Felix A.A. 2018. Pesticidal effects of extracts from Hyptis suaveolens and Hyptis spicigera on cowpea weevils. International Journal of Environment, Agriculture and Biotechnology 3(5):1691-1699.

Sharma, P.P., Roy, R.K., Anurag, G.D. and Sharma, V.K. 2013. Hyptis suaveolens (L.)
Poit: A phyto-pharmacological review. International Journal of Chemical and Pharmaceutical Sciences 4(1):1-11.

Sikirou, R., Arodokoun, D.Y., Bello, S., Hounsou, C.M., Zannou, E.T., EtchihaAfoha, S.A.P., Aboe, M.M., Zocli, B. and Bokonon Ganta, A.H. 2015. Évaluation de l'efficacité de PROTECT DP, insecticide binaire à base de Pyrimiphos-Méthyle et Deltamethrin, pour la lutte contre le charançon, Sitophilus zeamais dans les stocks de maïs au Bénin. Annales des Sciences Agronomiques 19(2):187-200.

Singleton, V.L., Orthofer, R. and LamuelaRaventos, R.M. 1999. Analysis of total phenols and other oxidation substrates and antioxidants by means of Folin-Ciocalteau reagent. Method Enzymology 299:152-178.

Ukeh, D.A., Birkett, M.A., Pickett, J.A., Bowman, A.S. and Luntz, A.J.M. 2009. Repellent activity of Alligator pepper, Aframomum melegueta and ginger, Zingiber officinale, against the maize weevil, Sitophilus zeamais. Phytochemistry 70:751-758. 